\title{
Psychrotolerant Microfungi Associated with Deer Mice (Peromyscus maniculatus) in a White-nose Syndrome Positive Bat Hibernaculum in Eastern Canada
}

\author{
Karen J. Vanderwolf ${ }^{1,2,3,4}$, David Malloch ${ }^{1}$, and Donald F. McAlpine ${ }^{1}$ \\ ${ }^{1}$ Department of Natural Science, New Brunswick Museum, 277 Douglas Avenue, Saint John, New Brunswick E2K 1E5 \\ Canada \\ ${ }^{2}$ Canadian Wildlife Federation, 350 Michael Cowpland Drive, Kanata, Ontario K2M 2W1 Canada \\ ${ }^{3}$ Current address: Department of Pathobiological Sciences, University of Wisconsin, 1656 Linden Drive, Madison, Wisconsin \\ 53706 USA \\ ${ }^{4}$ Corresponding author: kjvanderw@gmail.com
}

Vanderwolf, Karen J., David Malloch, and Donald F. McAlpine. 2017. Psychrotolerant microfungi associated with Deer Mice (Peromyscus maniculatus) in a white-nose syndrome positive bat hibernaculum in eastern Canada. Canadian FieldNaturalist 131(3): 238-245. https://doi.org/10.22621/cfn.v131i3.1906

With the exception of recent work on bats, no reports on the fungi present on live mammals in underground habitats have been published. We cultured psychrotolerant fungi from the external surface and faeces of live Deer Mice (Peromyscus maniculatus), and from the intestinal contents of a single freshly killed P. maniculatus, overwintering in a white-nose syndrome positive bat hibernaculum and from adjacent summer forest in eastern Canada. A low diversity of psychrotolerant fungi was cultured from $P$. maniculatus compared with that found in previous studies of the mycoflora of bats and arthropods occupying bat hibernacula in the region. Although the grooming habits of $P$. maniculatus may reduce the accumulation of a diverse psychrotolerant fungal assemblage on their external surface, we demonstrate that active euthermic mammals in underground habitats can carry viable spores of psychrotolerant fungi, both externally and internally. Small rodents using cave habitats may also play a role in dispersing psychrotolerant fungi between caves and suitable low-temperature habitats (i.e., burrows) in adjacent forest.

Key Words: Pseudogymnoascus destructans; Deer Mouse; Peromyscus maniculatus; cave fungi; cave mycota; cold-tolerant fungi; fungal dispersal; white-nose syndrome

\section{Introduction}

Mammals introduce organic matter, including fungal spores, into underground habitats, where nesting material, food caches, scat, carcasses, and shed hair and skin serve as substrates for various fungi (Nelson and Smith 1976; Jurado et al. 2010). The introduction to North American caves and cave-like habitats (i.e., mines; hereafter we include such habitats under the generic term "caves") of the psychrotolerant (cold-tolerant) fungus Pseudogymnoascus destructans, causative agent of the lethal bat disease, white-nose syndrome (WNS; Lorch et al. 2011), has prompted increased interest in the mycology of caves. However, with the exception of recent work focusing on bats (Johnson et al. 2013; Vanderwolf et al. 2013, 2016a; Lorch et al. 2015), no reports on the fungi present on live mammals in caves have been published. In addition, the literature on how psychrotolerant fungi might be dispersed from cave habitats is limited (Stephenson et al. 2007; Vanderwolf et al. 2016a,b).

Deer Mice (Peromyscus maniculatus Wagner, 1845) are a common and widespread North American small rodent that may reside in small numbers in caves, where available, during the winter (Trevor-Deutsch 1973). During the warmer months, this species disperses into surrounding woodland, staying relatively close to cave entrances in spring and early summer and ranging farther afield in late summer (Fenton 1970; Trevor-Deutsch 1973). Here we report on psychrotolerant fungi associated with overwintering $P$. maniculatus using cave habitat in eastern Canada, where overwintering bat populations were severely reduced after the 2011 arrival of the fungus Pseudogymnoascus destructans to the area (McAlpine et al. 2011). As a comparison, during the summer months, we also sampled fungi on mice from forest adjacent to this cave habitat.

\section{Methods \\ Winter Sampling}

Peromyscus maniculatus were live-trapped in Dorchester Mine, an abandoned copper mine and bat hibernaculum near Sackville, New Brunswick, 11-14 March 2014 (42 trap nights). Two trap sizes were used: $5.1 \times$ $6.4 \times 16.5 \mathrm{~cm}$ and $7.7 \times 8.9 \times 22.9 \mathrm{~cm}($ H. B. Sherman Traps, Inc., Tallahassee, Florida, USA). All traps were soaked in fungicide and rinsed prior to sampling. Traps were baited with a mixture of peanut butter and oats, furnished with cotton nesting material, checked daily, and re-baited as required. Traps were placed on the floor and on ledges along the walls adjacent to a mouse nest (1-2 $\mathrm{m}$ above the floor; Figure 1A), approximately 45$80 \mathrm{~m}$ from the mine entrance. The temperature in Dorchester Mine was measured using ibuttons (model DS1920-F5, Maxim Integrated Products Inc., Sunny- 
vale, California, USA) in the manner of Vanderwolf et al. (2012).

Each trapped mouse was transferred to a fresh plastic bag for swabbing by inverting the trap over the bag. Two swabs per mouse were taken using a new, sterile, dry, cotton-tipped applicator for each swab. The swabs were rubbed over the fur both dorsally and ventrally. After swabbing, the applicator was immediately streaked across the medium surface in a petri plate. Three diluting streaks were completed in the mine within $1 \mathrm{~h}$ of the initial streak, after which plates were sealed in situ with parafilm (Pechiney Plastic Packaging, Chicago, Illinois, USA). Two media types were inoculated for each mouse: dextrose-peptone-yeast extract agar (DPYA) and Sabouraud-dextrose agar (SDA), both of which were infused with the antibiotics chlortetracycline (30 $\mathrm{mg} / \mathrm{L})$ and streptomycin $(30 \mathrm{mg} / \mathrm{L})$. Mice were not directly handled or marked during any part of the procedure and were immediately released after sampling. One mouse was removed from the mine after swabbing of its external surface (New Brunswick Museum specimen 12946), euthanized using isoflurane, and the contents of its stomach, small intestine, and large intestine were spread on separate petri plates containing DPYA medium with no dilution.

Faeces produced by mice held in bags were transported to the lab for processing. Faeces $(\sim 3$ pellets per mouse) were suspended in $100 \mathrm{~mL}$ of autoclaved water and vigorously shaken for 10 minutes. The sample was then serially diluted five times, with $10 \mathrm{~mL}$ of each successive solution mixed with $90 \mathrm{~mL}$ of water. For each of the five dilutions, plus the undiluted sample, $10 \mathrm{~mL}$ were spread over the surface of separate petri plates containing hardened DPYA medium.

\section{Summer Sampling}

On the night of 27 August 2014, mice were trapped with live traps (100 trap nights) baited with bird seed adjacent to the entrance of Dorchester Mine. All traps were soaked in fungicide and rinsed the day before use. Mice were processed using the methods described above, except that faeces and intestinal contents were not collected. Three mice were swabbed twice, with one swab inoculated on DPYA medium and the other on SDA medium. For all other mice, only one swab was taken and inoculated on DPYA medium because of contamination issues with the SDA medium.

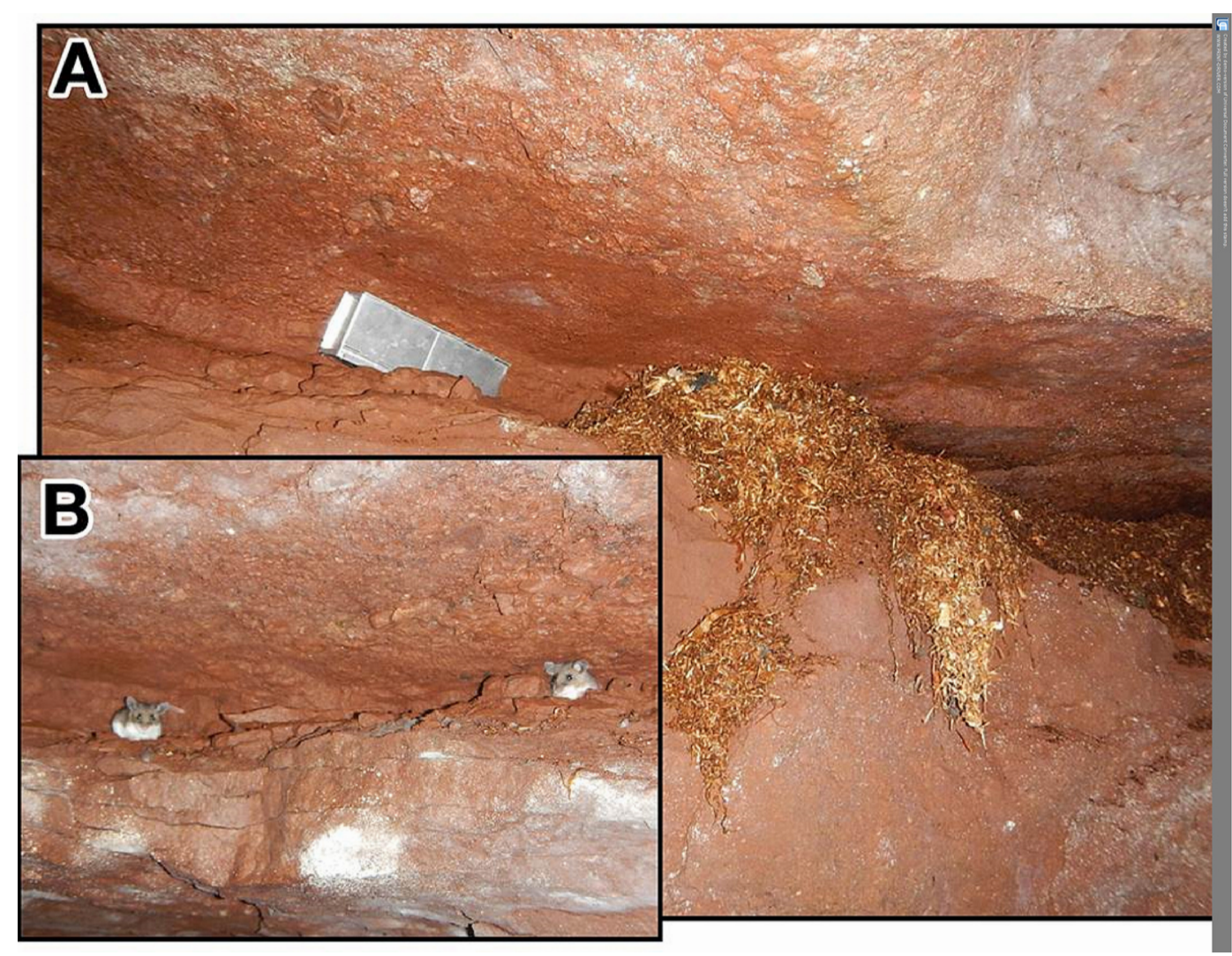

Figure 1. A. Deer Mouse (Peromyscus maniculatus) nesting material (a source and substrate for fungal spores) and a live trap in place on a wall ledge in Dorchester Mine near Sackville, New Brunswick. B. In winter, P. maniculatus were active in the dark zone on wall ledges and the floor of the mine. Photos: K. J. Vanderwolf. 


\section{Fungal Culturing and Data Analysis}

In the laboratory, samples were incubated, inverted, in the dark at $7^{\circ} \mathrm{C}$ in a low-temperature incubator (Model 2015, VWR International, Mississauga, Ontario, Canada) to approximate the subterranean environment and target psychrotolerant fungi. Samples were monitored over four months until either no new cultures had appeared for three weeks, or the plate had become overgrown with hyphae. Once fungi began growing on the plates, each distinct colony was subcultured to a new plate. DPYA without oxgall and sodium propionate was used for maintaining pure cultures (Figure 2). Identifications were carried out by comparing the micro- and macro-morphological characteristics of the microfungi to those traits appearing in the taxonomic literature and compendia (Domsch et al. 2007; Seifert et al. 2011) and by comparing isolates to a reference collection of fungi assembled from previous studies in underground habitats in the region, which were identified using a mix of morphological and molecular methods (Vanderwolf $e t$ al. 2013, 2016a,b). Permanent desiccant-dried vouchers of the collected fungi are deposited in the New Brunswick Museum mycological collection (NBM numbers F-05152-05155, 05161, 05163-05169, 05246-05256, 05359, 05364-05370, 05394-05400, 05521, 05626).

The numbers of fungal taxa per mouse were not normally distributed and subsequently were square-root transformed. A two-sample $t$ test was used to compare the number of fungal taxa per mouse for winter mice versus summer mice using Minitab software (Minitab Inc., Pennsylvania State University, Pennsylvania, USA).

\section{Results \\ Winter Sampling}

Six P. maniculatus were captured (two per night) during three days of sampling in Dorchester Mine. Nine fungal taxa and one sterile morph were cultured from the fur of mice sampled in the mine, with a mean of 2.83 fungal taxa per individual (standard deviation [SD] 0.75 , range $2-4, n=6$ mice). The second swab contributed 0.67 fungal taxa (SD 0.82, range $0-2$ ) that were not detected with the first swab. The most common fungal taxa were Pseudogymnoascus pannorum senso lato $(100 \%$ of mice; this fungal taxon is polyphyletic, S. Hambleton, personal communication to K.J.V.) and Penicillium spp. (50\%), while all other taxa were isolated from a single mouse each (Table 1).

Twelve fungal taxa and multiple sterile morphs were isolated from faeces collected from four mice, with a mean of 6.0 fungal taxa per individual (SD 2.83). Two mice did not produce scat before release. The most common fungal taxa cultured from feces were Mucor spp. (100\% of mice, $n=4)$, Pseudogymnoascus pannorum senso lato (75\%), Penicillium spp. (75\%), Cephalotrichum stemonitis (50\%), Thelebolus crustaceus (50\%), and Leuconeurospora capsici (50\%), while all other taxa were isolated from a single mouse each
(Table 1). Most fungal taxa were obtained from the undiluted sample and the first dilution; the fifth dilution produced no cultures. Seven fungal taxa plus one sterile morph were isolated from mouse gut contents.

The mean temperature in Dorchester Mine during the sampling period, March 2014, was $-0.98^{\circ} \mathrm{C}$ (SD 1.24) in the twilight zone and $6.63^{\circ} \mathrm{C}$ (SD 0.00) in the dark zone. The twilight zone ibutton was located $3 \mathrm{~m}$ inside the entrance. The mean temperature outside the mine, approximately $20 \mathrm{~m}$ from the entrance and above snow cover, was $-2.49^{\circ} \mathrm{C}$ (SD 5.31). Mice were generally observed on wall ledges and the floor deeper in the mine (Figure 1B) where air temperatures were warmer, and where they were subsequently captured.

\section{Summer Sampling}

Twenty-two fungal taxa plus five sterile morphs were cultured from 15 mice, with a mean of 4.87 fungal taxa per mouse (SD 2.13, range 2-8). Female mice $(n=8)$ carried a mean of 4.75 (SD 2.31) fungal taxa and males $(n=5)$ carried 4.6 (SD 2.30). Two mice escaped before sex was determined. The second swab contributed two fungal taxa (SD 2, range $0-4, n=3$ mice) that were not detected with the first swab. The most common fungal taxa were Mucor sp. (87\% of mice), Penicillium sp. (87\%), Cladosporium sp. (80\%), Pseudogymnoascus pannorum senso lato (47\%), Scopulariopsis sp. (20\%), Thysanophora sp. (20\%), Alternaria sp. (13\%), and Microascus sp. (13\%), while all other taxa were isolated from a single mouse each (Table 1). Summer mice captured outside the cave carried a significantly higher number of fungal taxa per individual than winter mice sampled inside the cave $\left(t_{1,18}=-2.48, P=0.024\right)$. The mean temperature in Dorchester Mine during August 2014 was $13.65^{\circ} \mathrm{C}$ (SD 0.76) in the twilight zone and $6.59^{\circ} \mathrm{C}(\mathrm{SD} 0.00)$ in the dark zone. The mean temperature outside of the mine, approximately $20 \mathrm{~m}$ from the entrance, was $18.12^{\circ} \mathrm{C}(\mathrm{SD} 4.21)$.

\section{Discussion}

Mice sampled during our study carried few fungi capable of growing at typical eastern Canadian dark zone cave temperatures, although summer mice carried a higher diversity of psychrotolerant fungi compared with mice swabbed during the winter. The psychrophilic Pseudogymnoascus destructans was not detected on mice, but isolates of a closely related species complex, Pseudogymnoascus pannorum senso lato, was cultured from all mice sampled during the winter and on half the mice sampled during the summer. Although only two bats (either Little Brown Myotis [Myotis lucifugus] or Northern Long-eared Myotis [M. septentrionalis]) were present in Dorchester Mine during the winter 2014 sampling period, viable $P$. destructans was present and was cultured from both walls (Vanderwolf et al. 2016c) and arthropods (Vanderwolf et al. 2016b) in the mine.

Pseudogymnoascus pannorum is commonly found on various substrates in caves, including hibernating 

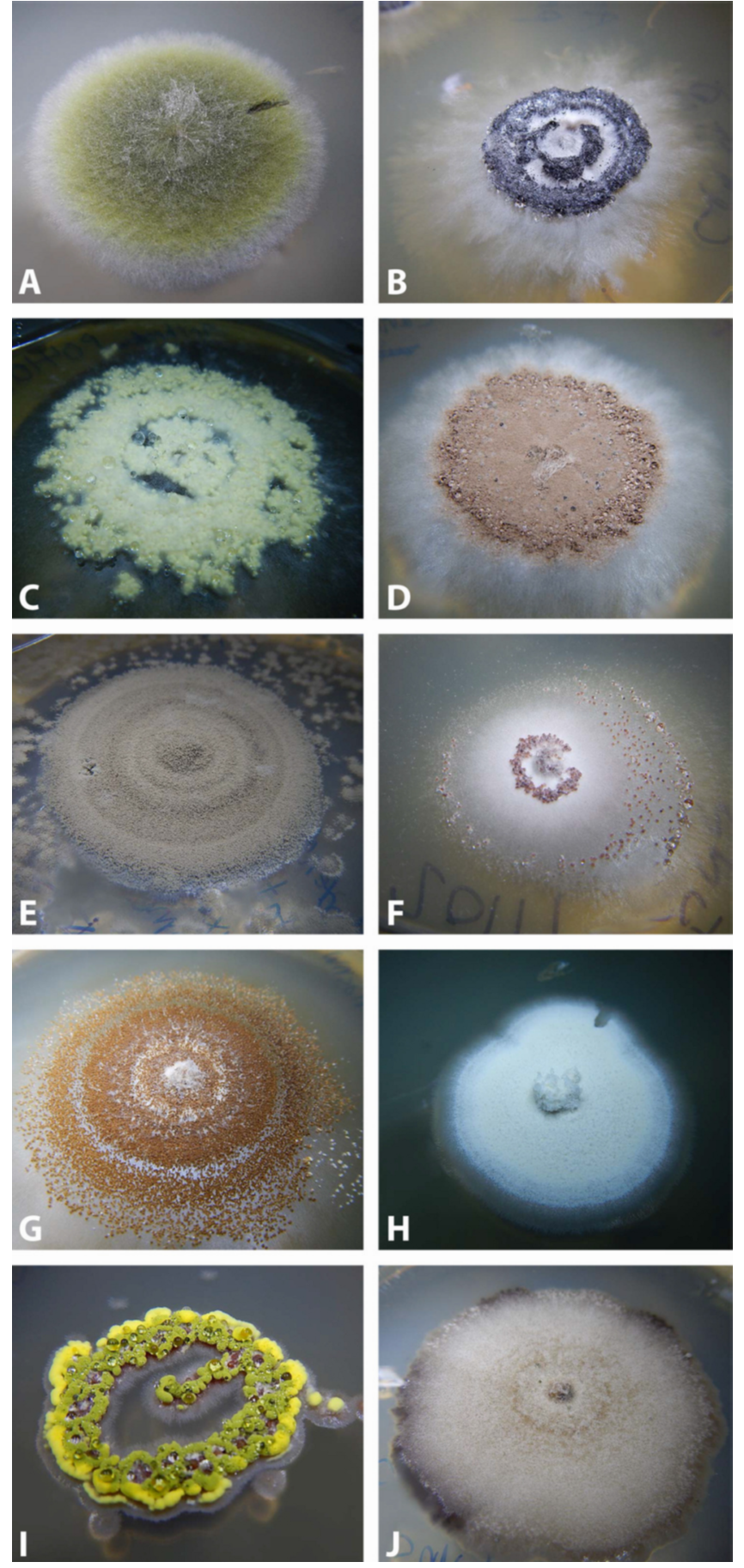

FiguRE 2. Representative psychotolerant fungi in pure culture from the winter (W) and summer (S) fur (FU), faeces (FE), and gut contents (GC) of Deer Mice (Peromyscus maniculatus) associated with a white-nose syndrome positive bat hibernaculum in eastern Canada. All cultures on DPYA without oxgall and sodium propionate. A. Alternaria sp. (S-FU); B. Arthrinium phaeospermum (S-FU); C. Arthoderma silverae (W-FU, W-GC); D. Microascus caviarformis (W-FU, W-FE, W-GC); E. Oidiodendron cf. state of Myxotrichium emodense (S-FU); F. Penicillium thomii (S-FU); G. Pseudogymnoascus roseus (W-FE); H. Scopulariopsis candida (S-FU); I. Talaromyces sp. (W-FU); J. Thysanophora canadensis (S-FU). Photos: K. J. Vanderwolf. 
TABLE 1. Psychrotolerant fungi cultured from the external surface of Deer Mice (Peromyscus maniculatus) captured inside a bat hibernaculum in winter 2014 and outside adjacent to the hibernaculum entrance in summer 2014, New Brunswick, Canada.

\begin{tabular}{|c|c|c|c|c|}
\hline \multirow[b]{2}{*}{ Fungus } & \multicolumn{3}{|c|}{ Winter (no. mice) } & \multirow{2}{*}{$\begin{array}{c}\text { Summer (no. mice) } \\
\text { Fur } \\
(n=15)\end{array}$} \\
\hline & $\begin{array}{l}\text { Fur } \\
(n=6)\end{array}$ & $\begin{array}{l}\text { Faeces } \\
(n=4)\end{array}$ & $\begin{array}{l}\text { Gut contents } \\
\quad(n=1)\end{array}$ & \\
\hline \multicolumn{5}{|l|}{ ASCOMYCOTA } \\
\hline Acremonium sp. & 0 & 0 & 0 & 1 \\
\hline Alternaria sp. & 0 & 0 & 0 & 2 \\
\hline Arthrinium phaeospermum (Corda) M.B. Ellis & 0 & 1 & 0 & 1 \\
\hline Arthroderma silverae Currah, S.P. Abbott \& Sigler & 1 & 0 & 1 & 0 \\
\hline Cephalotrichum stemonits (Pers.) Link & 0 & 2 & 0 & 0 \\
\hline Cladosporium sp. & 0 & 0 & 0 & 12 \\
\hline \multicolumn{5}{|l|}{ Leuconeurospora capsici (J. F. H. Beyma) } \\
\hline Malloch, Sigler \& Hambleton & 0 & 2 & 0 & 0 \\
\hline \multicolumn{5}{|l|}{ Leuconeurospora polypaeciloides Malloch, } \\
\hline Sigler and Hambleton & 0 & 0 & 0 & 1 \\
\hline Microascus sp. & 0 & 1 & 1 & 2 \\
\hline Microascus caviariformis Malloch \& Hubart & 1 & 1 & 1 & 0 \\
\hline Myxotrichum sp. & 0 & 0 & 0 & 1 \\
\hline Oidiodendron cf. state of Myxotrichum emodense & 0 & 0 & 0 & 1 \\
\hline Oidiodendron cf. hughesii, cf. myxotrichoides & 0 & 0 & 0 & 1 \\
\hline Paecilomyces sp. & 1 & 0 & 0 & 0 \\
\hline Penicillium sp. & 3 & 3 & 1 & 13 \\
\hline Penicillium thomii Maire & 0 & 0 & 0 & 1 \\
\hline \multicolumn{5}{|l|}{ Pseudogymnoascus pannorum senso lato (Link) } \\
\hline Minnis \& D.L. Lindner & 6 & 3 & 1 & 7 \\
\hline Pseudogymnoascus roseus Raillo & 0 & 1 & 0 & 0 \\
\hline Sarcinomyces sp. & 0 & 0 & 0 & 1 \\
\hline Scopulariopsis sp. & 1 & 0 & 0 & 1 \\
\hline Scopulariopsis candida Vuill. & 0 & 0 & 0 & 2 \\
\hline Talaromyces sp. & 1 & 0 & 0 & 0 \\
\hline Thelebolus sp. & 0 & 1 & 0 & 0 \\
\hline Thelebolus crustaceus (Fuckel) Kimbr & 0 & 2 & 0 & 0 \\
\hline Thysanophora canadensis Stolk \& Hennebert & 0 & 0 & 0 & 2 \\
\hline Thysanophora penicillioides (Roum.) W. B. Kendr. & 0 & 0 & 0 & 2 \\
\hline Trichoderma sp. & 0 & 0 & 0 & 1 \\
\hline Trichophyton sp. & 0 & 0 & 1 & 0 \\
\hline \multicolumn{5}{|l|}{ BASIDIOMYCOTA } \\
\hline Unidentified Basidiomycete & 0 & 0 & 0 & 1 \\
\hline Trichosporon sp. & 0 & 1 & 0 & 0 \\
\hline \multicolumn{5}{|l|}{ ZYGOMYCOTA } \\
\hline Mortierella sp. & 1 & 0 & 0 & 1 \\
\hline Mucor sp. & 1 & 4 & 1 & 13 \\
\hline Umbelopsis isabellina (Oudem.) W. Gams & 0 & 0 & 0 & 1 \\
\hline STERILE MORPH & 1 & 1 & 1 & 5 \\
\hline
\end{tabular}

bats (Johnson et al. 2013; Vanderwolf et al. 2013), and has been isolated from the fur of wild voles, shrews, mice, and rabbits outside caves (Hubalek et al. 1979; Chabasse 1988), as well as scat from Arctic Ground Squirrel (Spermophilus parryii; Kobayasi et al. 1967). Pseudogymnoascus pannorum appears to be a common component of the mycobiome of mammalian fur. However, $P$. pannorum is polyphyletic and the resolution of the species complex may reveal different ecological patterns.

Outside caves, the fungal diversity detected on mammals has generally been low. For example, the number of fungal isolates per Persian Squirrel (Sciurus anom- alus; $n=60$ ) varied from 0 to 4 (mean 2.6, SD 0.83) with 23 fungal species from 17 genera isolated overall (Rostami et al. 2010). Sierra et al. (2000) studied fungi on the fur of 85 Domestic Cats (Felis catus) and found the number of fungal genera per cat varied from 1 to 9 (mean 3.2). Dermatophytes, such as Arthroderma benhamiae, A. quadrifidum, A. persicolor, and Chrysosporium sp. have previously been isolated from $P$. maniculatus fur (Knudtson and Robertstad 1970; Hubalek 2000).

A greater diversity of fungi was cultured from mouse faeces than mouse fur and, paired with fungi cultured from mouse intestinal contents, demonstrate that mice 
are capable of transporting viable spores of psychrotolerant fungi internally. These spores may be acquired during feeding and grooming, as five of the fungal genera cultured from faeces were also found on fur. Although faeces collected from the traps may have acquired spores from the environment, Kohl et al. (2015) found no significant difference in the microbiome between Desert Woodrat (Neotoma lepida) faeces collected aseptically and faeces collected from live traps.

Macrofungi and mycorrhizal fungi are part of the omnivorous diet of $P$. maniculatus, and viable spores of these fungi are frequently detected in their faeces and stomach contents outside caves (Maser and Maser 1987; Pyare and Longland, 2001; Frank et al. 2006; D'Avla et al. 2007; Meyer et al. 2015). It is thought that $P$. maniculatus and other rodents play a role in dispersing fungal spores across the landscape, which is of particular importance with regard to mycorrhizal inoculum (Maser and Maser 1987; Pyare and Longland 2001; Frank et al. 2006; D'Avla et al. 2007; Meyer et al. 2015). However, mice are unlikely to transport fungal spores great distances internally, as Cork and Kenagy (1989) found that the mean retention time of Elaphomyces granulatus spores was $12.0 \mathrm{~h}$ (standard error 2.4) in P. maniculatus.

Nevertheless, evidence suggests that mice opportunistically feed on fungi growing in caves, such as those growing on live and dead bats, decaying leaf litter, and woody debris, or consume spores concomitant with other cave food sources such as arthropods (Peck 1988) and bats (Trevor-Deutsch 1973). Therefore, mice likely play a role in fungal dispersal in underground environments. For example, we observed Microascus caviariformis growing in Dorchester Mine, and we subsequently isolated viable spores of this fungus from mouse faeces and from the gut contents. This fungus has rarely been isolated, and never outside caves (Malloch and Hubart 1987; Vanderwolf et al. 2013, 2016a).

It is noteworthy that a full $33 \%$ of the summer isolates from mice were members of the genus Microascus, including related asexual anamorphs assigned to Scopulariosis spp. Species of Microascus lack the forcible discharge of ascospores common to most ascomycetes and occur in habitats where access to freely flowing air currents is limited. For species of Microascus, such habitats include stored grains, soil, dung, and caves (Barron 1961; Vanderwolf et al. 2013; SandovalDenis et al. 2016).

Once P. maniculatus leave caves in the spring and disperse into the outside environment (Trevor-Deutsch 1973), they may carry spores of psychrotolerant fungi with them, both internally and externally, to woodland burrow systems. Winter and summer burrow temperatures of Peromyscus spp. across a diversity of habitats in North America fall within the range of temperatures at which psychrotolerant fungi will grow, e.g., mean of $10-15^{\circ} \mathrm{C}$ during summer and $0-6^{\circ} \mathrm{C}$ during winter in British Columbia, depending on habitat (Hayward
1965). Burrow microclimate may have contributed to the diversity of psychrotolerant fungi we cultured from the fur of mice during the summer.

Several of the fungal genera we isolated from faeces are coprophilous, such as Cephalotrichum stemonitis, Thelebolus spp., and Arthroderma silverae (Currah et al. 1996; Domsch et al. 2007). Other fungal taxa, especially those we isolated from mice during the summer, such as Alternaria spp., Arthrinium phaeospermum, and Thysanophora spp., are often associated with plants (Domsch et al. 2007). Genera such as Mucor, Cladosporium, and Penicillium are ubiquitous in the outside environment (Domsch et al. 2007) and were more commonly isolated from mice sampled outside the mine than inside.

The relatively low psychrotolerant fungal diversity found on mice during this study is in marked contrast to the diverse fungal assemblage isolated from bats hibernating in caves in the region (Vanderwolf et al. 2013, 2016a) and even arthropods at the same site (Vanderwolf et al. 2016b). For example, using similar methods, a mean of 8.3 (SD 3.2) fungal taxa per individual were cultured from Harvestmen (Nelima elegans; $n=9$ ) overwintering in Dorchester Mine.

Peromyscus maniculatus remain active throughout the winter and hence do not undergo a drop in body temperature, unlike hibernating bats. This may decrease the diversity of psychrotolerant fungi on the external surface of Peromyscus. Perhaps more important, rodents are effective groomers (Murray 1961; Hallman et al. 1993), and P. maniculatus overwintering in caves are likely to groom more frequently than hibernating bats. Mammals that regularly groom are able to limit ectoparasites (Murray 1961) and may also be able to limit the mycobiome they carry on their fur, including dermatophytes and psychrotolerant fungi.

Although the sample size of mice available to us was small, this study demonstrates that euthermic mammals occupying caves can carry a variety of viable spores of psychrotolerant fungi, both externally and internally. Small rodents using cave habitats may also play a role in dispersing psychrotolerant fungi between caves and suitable low-temperature habitats (i.e., burrows) in adjacent forest.

\section{Acknowledgements}

We thank John Klymko and Sarah Robinson for assisting with winter fieldwork and S. Hambleton (Agriculture Canada, Ottawa, Ontario, Canada) for discussions on fungal taxonomy. Howie Huynh kindly assisted with summer fieldwork. Research funding was provided by the New Brunswick Wildlife Trust Fund, Crabtree Foundation, New Brunswick Environmental Trust Fund, New Brunswick Department of Natural Resources, and Parks Canada. We also thank the Department of Energy and Resource Development for approving our request to euthanize a single Deer Mouse and to live-trap more generally in Dorchester Mine. 


\section{Literature Cited}

Barron, G. L., R. F. Cain, and J. C. Gilman. 1961. The genus Microascus. Canadian Journal of Botany 39: 1609-1631. https://doi.org/10.1139/b61-143

Chabasse, D. 1988. Taxonomic study of keratinophilic fungi isolated from soil and some mammals in France. Mycopathologia 101: 133-140. https://doi.org/10.1007/BF0043 7030

Cork, S. J., and G. J. Kenagy. 1989. Rates of gut passage and retention of hypogeous fungal spores in two forest dwelling rodents. Journal of Mammalogy 70: 512-519. https://doi .org/10.2307/1381423

Currah, R. S., S. P. Abbott, and L. Sigler. 1996. Arthroderma silverae sp. nov. and Chrysosporium vallenarense, keratinophilic fungi from arctic and montane habitats. Mycological Research 100: 195-198. https://doi.org/10.1016/s 0953-7562(96)80121-3

D'Alva, T., C. Lara, A. Estrada-Torres, and C. CastilloGuevara. 2007. Digestive responses of two omnivorous rodents (Peromyscus maniculatus and P. alstoni) feeding on epigeous fungus (Russula occidentalis). Journal of Comparative Physiology B 177: 707-712. https://doi.org/10 .1007/s00360-007-0188-X

Domsch, K. H., W. Gams, and T.-H. Anderson. 2007. Compendium of Soil Fungi. Second edition. IHW-Verlag, Berlin, Germany.

Fenton, M. B. 1970. Population studies of Myotis lucifugus (Chiroptera: Vespertilionidae) in Ontario. Life sciences contribution 77. Royal Ontario Museum, Toronto, Ontario, Canada.

Frank, J. L., S. Barry, and D. Southworth. 2006. Mammal mycophagy and dispersal of mycorrhizal inoculum in Oregon white oak woodlands. Northwest Science 80: 264 273.

Hallman, T. M., L. C. Adams, D. J. Mullins, and J. R. Tester. 1993. Duration of effectiveness of fluorescent pigment when tracking small mammals. Canadian Field-Naturalist 107: 370-372. Accessed 23 December 2017. https: //www.biodiversitylibrary.org/item/108204\#page/386/mode /1up.

Hayward, J. S. 1965. Microclimate temperature and its adaptive significance in six geographical races of Peromyscus. Canadian Journal of Zoology 43: 341-350. https://doi.org /10.1139/z65-033

Hubalek, Z. 2000. Keratinophilic fungi associated with freeliving mammals and birds. Revista Iberoamericana de Micologia 17: 93-103.

Hubalek, Z., B. Rosicky, and M. Otcenasek. 1979. Fungi on the hair of small wild mammals in Czechoslovakia and Yugoslavia. Ceska Mykologie 33: 81-93.

Johnson, L. J. A. N., A. N. Miller, R. A. McCleery, R. McClanahan, J. A. Kath, S. Lueschow, and A. PorrasAlfaro. 2013. Psychrophilic and psychrotolerant fungi on bats and the presence of Geomyces spp. on bat wings prior to the arrival of white nose syndrome. Applied Environmental Microbiology 79: 5465. https://doi.org/10.1128/ AEM.01429-13

Jurado, V., E. Porca, S. Cuezva, A. Fernández-Cortès, S. Sanchez-Moral, and C. Saiz-Jimenez. 2010. Fungal outbreak in a show cave. Science of the Total Environment 408: 3632-3638. https://doi.org/10.1016/j.scitotenv.2010 .04 .057

Knudtson, W. U., and G. W. Robertstad. 1970. The isolation of keratinophilic fungi from soil and wild animals in
South Dakota. Mycopathologia et Mycologia Applicata 40: 309-323. https://doi.org/10.1007/BF02051784

Kobayasi, Y., N. Hiratsuka, R. P. Korf, K. Tubaki, K. Aoshima, M. Soneda, and J. Sugiyama. 1967. Mycological studies of the Alaskan Arctic. Annual Report, Institute Fermentation, Osaka 3: 1-138.

Kohl, K. D., K. Luong, and M. D. Dearing. 2015. Validating the use of trap-collected feces for studying the gut microbiota of a small mammal (Neotoma lepida). Journal of Mammalogy 96: 90-93. https://doi.org/10.1093/jmammal /gyu008

Lorch, J. M., C. U. Meteyer, M. J. Behr, J. G. Boyles, P. M. Cryan, A. C. Hicks, A. E. Ballmann, J. T. Coleman, D. N. Redell, D. M. Reeder, and D. S. Blehert. 2011. Experimental infection of bats with Geomyces destructans causes white-nose syndrome. Nature 480: 376-378. https://doi .org/10.1038/nature 10590

Lorch, J. M., A. M. Minnis, C. U. Meteyer, J. A. Redell, J. P. White, H. M. Kaarakka, L. K. Muller, D. L. Lindner, M. L. Verant, V. Shearn-Bochsler, and D. S. Blehert. 2015. The fungus Trichophyton redellii sp. nov. causes skin infections that resemble white-nose syndrome of hibernating bats. Journal of Wildlife Diseases 51: 36-47. http://doi .org/10.7589/2014-05-134

Malloch, D., and J. M. Hubart. 1987. An undescribed species of Microascus from the Cave of Ramioul. Canadian Journal of Botany 65: 2384-2388. https://doi.org/10.1139/b87324

Maser, C., and Z. Maser. 1987. Notes on mycophagy in four species of mice in the genus Peromyscus. Great Basin Naturalist 47: 308-313.

McAlpine, D. F., K. J. Vanderwolf, G. J. Forbes, and D. Malloch. 2011. Consumption of bats (Myotis spp.) by raccoons (Procyon lotor) during an outbreak of white-nose syndrome in New Brunswick: implications for bat mortality estimates. Canadian Field-Naturalist 125: 257-260. https:// doi.org/10.22621/cfn.v125i3.1231

Meyer, R. T., A. Weir, and T. R. Horton. 2015. Small-mammal consumption of hypogeous fungi in the central Adirondacks of New York. Northeastern Naturalist 22: 648-651. https://doi.org/10.1656/045.022.0318

Murray, M. D. 1961. The ecology of the louse Polyplax serrata (Burn.) on the mouse Mus musculus L. Australian Journal of Zoology 9: 1-13. https://doi.org/10.1071/ZO 9610001\#sthash.eiyWA4ys.dpuf

Nelson, B. C., and C. R. Smith. 1976. Ecological effects of a plague epizootic on the activities of rodents inhabiting caves at Lava Beds National Monument, California. Journal of Medical Entomology 13: 51-61. https://doi.org/10.1093 /jmedent/13.1.51

Peck, S. B. 1988. A review of the cave fauna of Canada, and the composition and ecology of the invertebrate fauna of caves and mines in Ontario. Canadian Journal of Zoology 66: 1197-1213. https://doi.org/10.1139/z88-176

Pyare, S., and W. S. Longland. 2001. Patterns of ectomycorrhizal-fungi consumption by small mammals in remnant old-growth forests of the Sierra Nevada. Journal of Mammalogy 82: 681-689. https://doi.org/10.1644/1545-1542(20 01) $082<0681$ :POEFCB $>2.0 . \mathrm{CO} ; 2$

Rostami, A., D. Shirani, H. Shokri, A. R. Khosravi, R. Daieghazvini, and Z. Tootian. 2010. Fungal flora of the hair coat of Persian squirrel (Sciurus anomalus) with and without skin lesion in Tehran, Iran. Journal of Mycologie 
Medicale 20: 21-25. https://doi.org/10.1016/j.mycmed.20 09.11 .004

Sandoval-Denis, M., J. Gené, D. A. Sutton, J. F. Cano-Lira, G. S. de Hoog, C. A. Decock, N. P. Wiederhold, and J. Guarro. 2016. Redefining Microascus, Scopulariopsis and allied genera. Perssonia 36: 1-36. https://doi.org/10.3767 /003158516X688027

Seifert, K., G. Morgan-Jones, W. Gams, and B. Kendrick. 2011. The Genera of Hyphomycetes. CBS-KNAW Fungal Biodiversity Centre, Utrecht, Netherlands.

Sierra, P., J. Guillot, H. Jacob, S. Bussieras, and R. Chermette. 2000. Fungal flora on cutaneous and mucosal surfaces of cats infected with feline immunodeficiency virus or feline leukemia VI. American Journal of Veterinary Research 61: 158-161. https://doi.org/10.2460/ajvr.2000.61 .158

Stephenson, S., M. Slay, C. Slay, and A. Tuggle. 2007. Cave crickets (Orthoptera: Rhaphidophoridae) as vectors of Dictyostelids (Protista: Dictyosteliida). Entomological News 118: 292-295. http://doi.org/10.3157/0013-872X(2007)118 [292:CCOAVO]2.0.CO;2

Trevor-Deutsch, B. 1973. The role of hibernating bats in the winter diet of Peromyscus spp. (Rodentia; Cricetidae). Ph.D. thesis, Carleton University, Ottawa, Ontario, Canada.

Vanderwolf, K. J., D. F. McAlpine, G. J. Forbes, and D. Malloch. 2012. Winter bat populations and cave microclimate prior to and at the onset of white-nose syndrome in
New Brunswick. Canadian Field-Naturalist 126: 125-134. https://doi.org/10.22621/cfn.v126i2.1327

Vanderwolf, K. J., D. F. McAlpine, D. Malloch, and G. J. Forbes. 2013. Ectomycota associated with hibernating cave bats in eastern Canada prior to the emergence of white-nose syndrome. Northeastern Naturalist 20: 115-130. https://doi .org/10.1656/045.020.0109

Vanderwolf, K. J., D. Malloch, and D. F. McAlpine. 2016a. Fungi on white-nose infected bats (Myotis spp.) in Eastern Canada show no decline in diversity associated with Pseudogymnoascus destructans (Ascomycota: Pseudeurotiaceae). International Journal of Speleology 45: 43-50. https: //doi.org/10.5038/1827-806X.45.1.1946

Vanderwolf, K. J., D. Malloch, and D. F. McAlpine. 2016b. Ectomycota associated with arthropods from bat hibernacula in eastern Canada, with particular reference to Pseudogymnoasucs destructans. Insects 7: 16. https://doi.org/ 10.3390/insects 7020016

Vanderwolf, K. J., D. Malloch, and D. F. McAlpine. 2016c. Detecting viable Pseudogymnoascus destructans (Ascomycota: Pseudeurotiaceae) from walls of bat hibernacula: effect of culture media. Journal of Cave and Karst Studies 78: 158-162. https://doi.org/10.4311/2015MB0138

Received 23 February 2017

Accepted 31 August 2017 